Allen, L. A., Pasley, Sheila M. \& Pierce, Margaret A. F. (1952). J.gen. Microbiol. 7, 36-43

\title{
Some Factors affecting the Viability of Faecal Bacteria in Water
}

\author{
By L. A. ALLEN, SHEILA M. PASIEY and MARgaRET A. F. PIERCE \\ Water Pollution Research Laboratory, Langley Road, Watford, Hertfordshire
}

SUMMARY: The effect of various conditions on the rate of death of Bacterium coli and of Streptococcus faecalis in dilute buffer solutions was followed by making colony counts at intervals during prolonged periods of incubation and then constructing mortality curves. The form of these curves was characteristic for each organism. Of the $\mathrm{pH}$ values investigated (approximately $5,6,7$ and 8 ) both organisms were least viable in the range 6 to 7 . Strep. faecalis was not affected by the degree of oxygenation of the water but Bact. coli died much more rapidly under anaerobic than under aerobic conditions.

Growth of Bact. coli was observed with as little as 0.28 part per million organic matter in solution. A much higher concentration of nutriment was required for growth of Strep. faecalis; with a concentration slightly below that required for growth the viable population remained virtually stable for a long period. The rate of death depended on the age of the cells at the time of immersion in water.

Factors affecting the longevity in water of organisms used as indices of pollution are of importance in the sanitary survey of rivers or in assessing the suitability of water for drinking purposes. Reports in the literature suggest that the period of survival may be conditioned by a number of factors but the conclusions drawn are often open to doubt owing to failure to arrange for conditions to be the same in comparable experiments. Moreover, in earlier work there is often some doubt of the precise characters of the organism referred to as Bacterium coli. Very few observations appear to have been made on the longevity of Streptococcus faecalis.

\section{ME'THODS}

The factors studied were $\mathrm{pH}$ value, oxygen tension, concentration of nutrient material, and age of culture at time of immersion in water. In the investigation of any one factor, precautions were taken to ensure that other conditions remained constant. The strains of bacteria used had all been isolated from sewage or river water and before use in this work were tested for characteristic reactions. These were: Bact. coli (type I): Gram negative, non-sporing short rod, indole +, MR +, VP - , citrate -, acid and gas in MacConkey broth at $44^{\circ}$; Strep. faecalis: Gram positive coccus in pairs and short chains, acid clot in litmus milk, growth at $45^{\circ}$, growth in broth containing $6.5 \%$ sodium chloride, survives heating for $30 \mathrm{~min}$. at $60^{\circ}$, growth at $\mathrm{pH} 9 \cdot 6$. Incubation was at $20^{\circ}$ unless otherwise stated.

Very dilute phosphate buffer solution $(0 \cdot 003 \mathrm{M})$ was used as the suspending fluid, a concentration sufficient to maintain the $\mathrm{pH}$ value virtually constant throughout the course of an experiment. The solution was sterilized by auto- 
claving either in hard glass bottles fitted with stoppers or in conical flasks covered with beakers; cotton wool or other organic material was not allowed in contact with the buffer or with the inside of a flask. Unless anaerobic conditions were being studied the solution was aerated with sterile diffused air for $1 \mathrm{hr}$. before use.

Colony counts were made either in Petri dishes or by the spinning bottle technique described by Proom \& Hemmons (1949). Nutrient agar was used as the medium for Bact. coli, glucose yeast extract agar for Strep. faecalis; inoculated plates and bottles of both media were incubated at $37^{\circ}$.

\section{RESLL'TS}

Form of death curve

When numbers of surviving bacteria, expressed as percentages, were plotted against the periods for which the culture had been suspended in buffer, the form of the curve was usually sigmoid, as in Fig. 1. Such curves approached the horizontal axis so gradually that an exact period of survival could not be estimated. When, however, the percentages of bacteria surviving were replaced by the logarithms of the percentages, the curves approached the horizontal axis much more steeply, as in Fig. 2. The period of survival was therefore conveniently expressed as the time corresponding to the point of intersection of such a curve with the axis, i.e. the time required for destruction of $99 \%$ of the cells originally present.

The curves for Bact. coli and Strep. faecalis were characteristically of different shapes, and corresponded to the two principal types of deviation from the logarithmic form discussed by Hinshelwood (1951).

With Bact. coli a large section of the 'log-survivors' curve sometimes approximated to a straight line, as in Fig. 2 (Bact. coli), but often the final stages of decline might be abnormally protracted so that the curve turned outwards at the lower end, as in Fig. 3 and in curve $\boldsymbol{A}$, Fig. 5. This could be explained by the presence of cells of abnormally high resistance, which Hinshelwood suggests may arise from a previous mutation. Some support for this view was obtained in one set of experiments where the deviation was particularly marked and plate cultures of the declining population showed the presence of both smooth and rough forms of colony, both of which when tested gave characteristic reactions for Bact. coli. This variation was, however, only transient for, on preparing cultures from the two types of colony and comparing their rates of decline when suspended in dilute buffer solution, both the 'log-survivors' curves were found to approximate closely to straight lines and to show very similar rates of decline. Platings from both these suspensions now showed the presence of only smooth colonies.

With Strep. faecalis some time elapsed before the lethal action of the water took full effect but then it acted comparatively rapidly. The 'log-survivors' curve sloped very gently at first and then quite steeply. In some tests there was no appreciable diminution in count for several days and then in a further similar period of time the suspension was virtually totally destroyed. 


\section{Effect of $\mathrm{pH}$ value}

Rates of death were determined at $\mathrm{pH}$ values approximately $5,6,7$ and 8 , in buffer solutions containing 5 parts per million (p.p.m.) of an $18 \mathrm{hr}$. nutrient broth culture of Bact. coli or 3 p.p.m. of a 72 hr. culture of Strep. faecalis in glucose-yeast extract broth. Fourfold colony counts were made on the contents of duplicate flasks at intervals during incubation. Rates of death in duplicate flasks were found to be of the same order, but there were profound

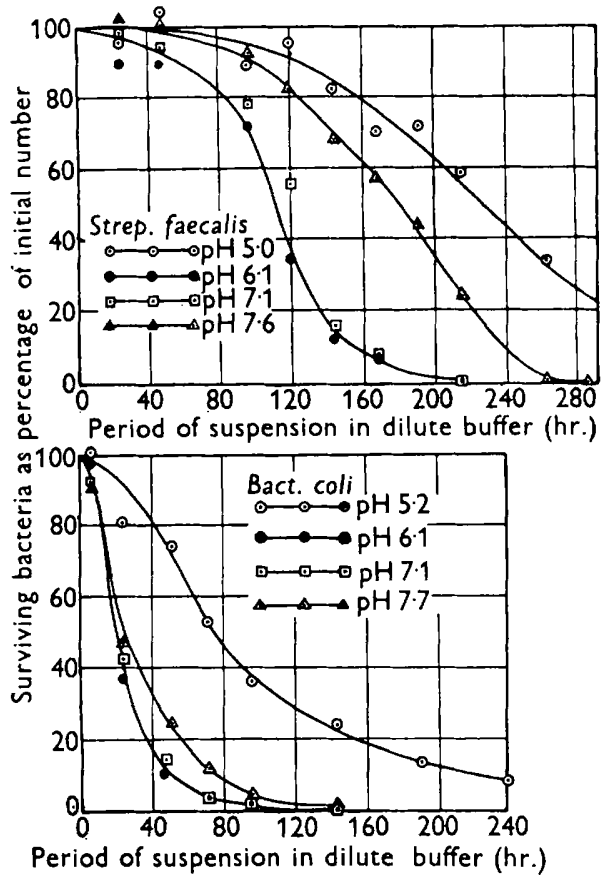

Fig. 1
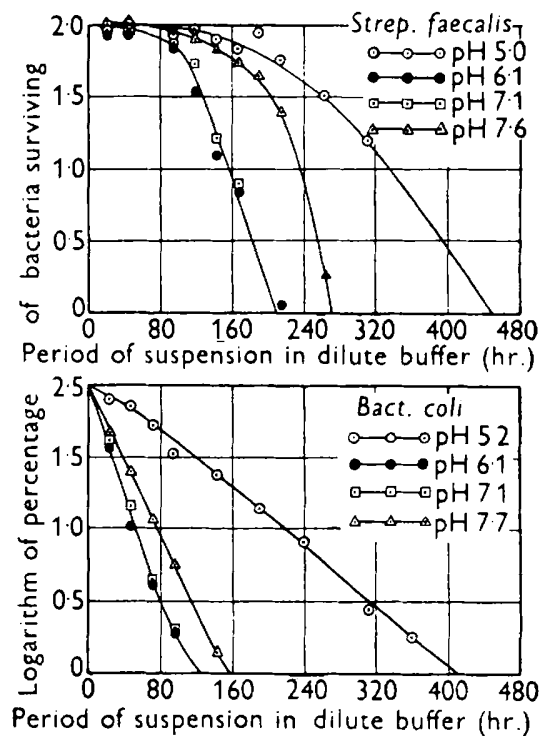

Fig. 2

Fig. 1. Rate of death of Bact. coli and of Strep. faecalis in $0.003 \mathrm{~m}$ phosphate buffer at different $\mathrm{pH}$ values.

Fig. 2. Rate of death of Bact. coli and of Strep. faecalis in 0.003 $\mathrm{x}$ phosphate buffer at different $\mathrm{pH}$ values (logarithmic scale).

differences between average rates of death at different $\mathrm{pH}$ values. Fig. 1 , in which the averages of the eight values are plotted, shows the same trend for both organisms; viability is greatest at $\mathrm{pH} 5 \cdot 0-5 \cdot 2$, least at $\mathrm{pH} 6 \cdot 1-7 \cdot 1$ and

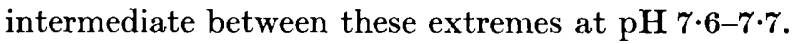

\section{Effect of oxygen tension}

Rates of death of each organism under aerobic and anaerobic conditions were compared. For several hours before use a current of sterile nitrogen was passed through the liquid in the bottles to be used for anaerobic conditions, anaerobiosis being confirmed by testing for dissolved oxygen by the micro method of Fox \& Wingfield (1938). The buffer for aerobic experiments was 
aerated with a current of sterile air. Four bottles (two aerobic and two anaerobic) were each inoculated with 5 p.p.m. of an $18 \mathrm{hr}$. broth culture of the test organism. Before and immediately after each sampling a current of air or nitrogen was passed through the suspensions and the bottles were then resealed. In all aerobic bottles the liquid remained virtually saturated throughout the experiments. In the anaerobic bottles containing Bact. coli the dissolved oxygen remained between 1.5 and $4.0 \%$ of saturation for the first 3 days and between 9 and $18 \%$ for the next 6 days; in those inoculated with Strep. faecalis it was between 1 and $6 \%$ of saturation during the first 6 days of incubation, after which no further values were obtained.

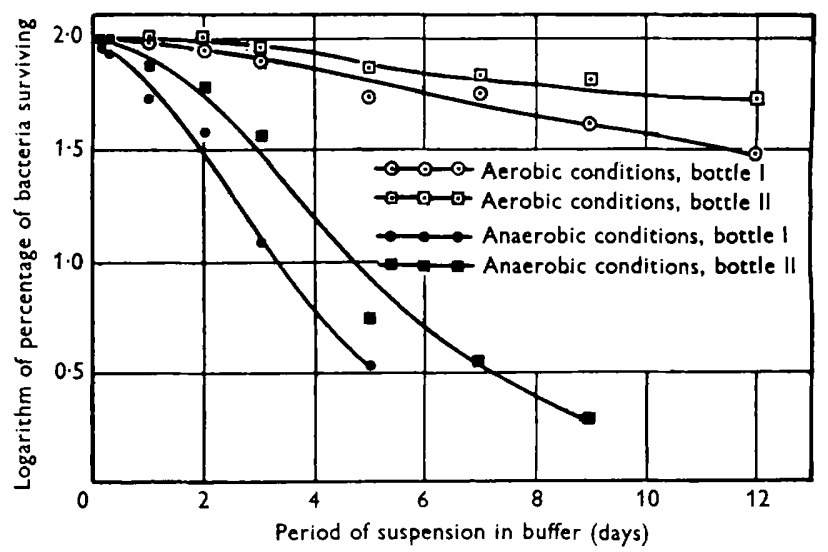

Fig. 3. Rate of death of Bact. coli in $0 \cdot 003 \mathrm{M}$ phosphate buffer at $\mathrm{pH} 6 \cdot 0$ under aerobic and anaerobic conditions.

Results (expressed graphically in Figs. 3 and 4) show that Bact. coli died much more rapidly under anaerobic than under aerobic conditions, a finding similar to that observed by Whipple \& Mayer (1906) for Salmonella typhi. With Strep. faecalis, on the other hand, there was no significant difference in the rates of mortality under the two conditions.

\section{Effect of small concentrations of nutrient material}

Reports in the literature suggest that growth of bacteria in water containing only traces of nutrient material may depend on a number of conditions. Savage \& Wood (1917) found that, whereas streptococci did not multiply in sterile tap water, Bact. coli showed an increase in every test. Butterfield (1929) recorded growth of Bact. aerogenes in media containing 0.5 p.p.m. glucose and 0.5 p.p.m. peptone, ZoBell \& Grant (1943) of heterotrophic marine bacteria in mineral solutions containing as little as 0.1 p.p.m. peptone or glucose, and Burke \& Taschner (1936) of Bact. coli in water containing sufficient potato extract to give a figure for 'oxygen consumed' of 0.51 p.p.m. or above. Heukelekian \& Heller (1940) found that by increasing the effective surface (for example by adding glass beads) appreciable growth of Bact. coli was 
obtained at much lower concentrations of nutrient material than normally. This effect of surface was thought by ZoBell (1943) to be largely due to concentration of nutrient material on it. Bigger (1937) observed that one strain of Bact. coli attained numbers of several hundred thousand $/ \mathrm{ml}$. in sterilized tap water and over a prolonged period of storage the population showed pronounced rises and falls. Further experiments (Bigger \& Nelson, 1941, 1943) showed that, provided ammonia and carbon dioxide were present, Bact. coli would grow in distilled water containing talc or one of a number of other inorganic materials in a finely divided or porous condition.

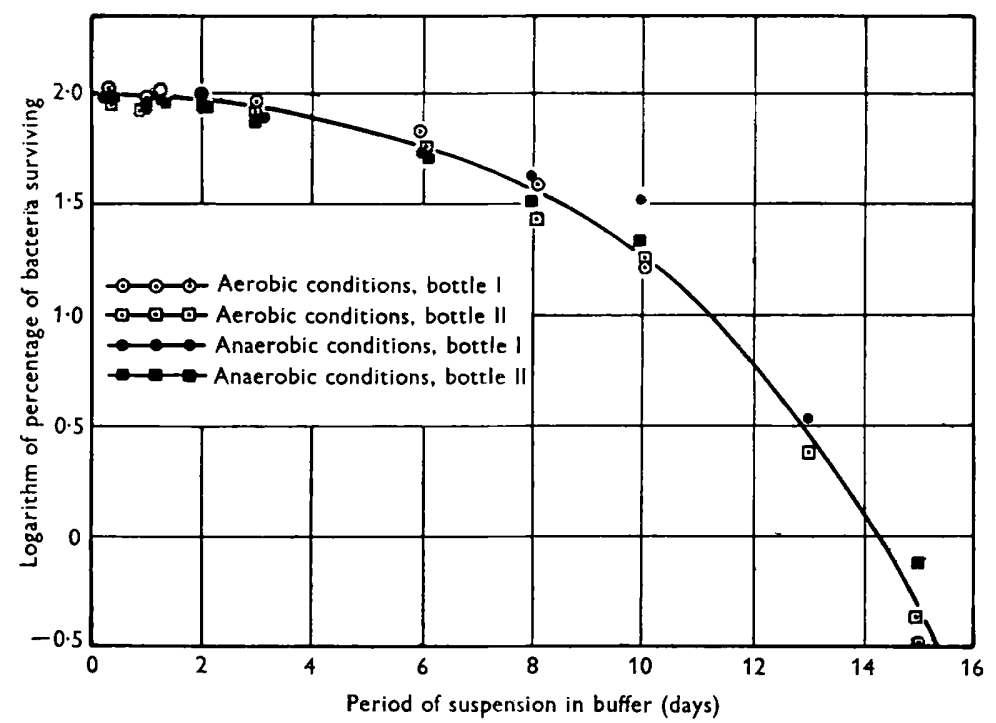

Fig. 4. Rate of death of Strep. faecalis in $0.003 \mathrm{M}$ phosphate buffer at $\mathrm{pH} 6 \cdot 0$ under aerobic and anaerobic conditions.

Observations on the effect of small concentrations of nutrient material on viability were made with suspensions of organisms which had been freed as far as possible from organic matter by repeatedly centrifuging and resuspending in buffer solution. Measured quantities of appropriate dilutions of glucoseyeast extract broth $(0.3 \%$ Yeastrel, $2 \%$ peptone, $0.5 \%$ glucose, and $1 \%$ Lemco) were added to separate bottles of the bacterial suspension to give concentrations ranging from nil to several hundred p.p.m.

Two sets of experiments were carried out with each species of organism, the first with a pure culture of a single strain, the second with a mixture of several strains. Freedom from contamination was established periodically throughout the experiments by picking colonies from the plates and testing their characters.

The average counts recorded in these experiments are shown in Tables 1 and 2. Growth of the mixed strains of Bact. coli occurred at much lower concentrations of nutrient material than with the single strain and the level of population eventually maintained increased with the concentration of nutriment. The lowest concentration of broth in which substantial growth occurred 
Table 1. Effect of small concentrations of nutrient material on viability of Bact. coli in $0.003 \mathrm{~m}$ phosphate buffer at $\mathrm{pH} 6 \cdot 0$.

(Surviving bacteria as colony counts/ml. of suspension, each figure being the average of three counts.)

\begin{tabular}{|c|c|c|c|c|c|c|}
\hline \multirow{3}{*}{$\begin{array}{c}\text { Period of } \\
\text { suspension } \\
\text { in buffer } \\
\text { (hr.) }\end{array}$} & \multicolumn{6}{|c|}{ Concentration of added broth (p.p.m.) } \\
\hline & $\mathbf{0}$ & $2 \cdot 5$ & 10 & 25 & 100 & 250 \\
\hline & \multicolumn{6}{|c|}{ Colony counts/ml. suspension } \\
\hline \multicolumn{7}{|c|}{ Exp. I. Pure culture of single strain: } \\
\hline o & 2,340 & 2,280 & - & 2,390 & - & 2,080 \\
\hline 23 & 900 & 299 & - & 290 & - & $>20,000$ \\
\hline 44 & 374 & 101 & - & 457 & 一 & $>20,000$ \\
\hline 71 & 193 & 81 & 一 & 585 & 一 & $>20,000$ \\
\hline 95 & 131 & 61 & - & 548 & - & $6,200,000$ \\
\hline 143 & 81 & 46 & - & 356 & - & $100,000,000$ \\
\hline 240 & 34 & 26 & - & 37 & - & $7,400,000$ \\
\hline 336 & 27 & 14 & - & 9 & 一 & $2,980,000$ \\
\hline 432 & 20 & 8 & - & 4 & - & $3,550,000$ \\
\hline 504 & 9 & 2 & - & 2 & - & $2,740,000$ \\
\hline 583 & 4 & 0 & - & 0 & 一 & $2,790,000$ \\
\hline 672 & 1 & 0 & - & 0 & - & $3,810,000$ \\
\hline 744 & 0 & $\mathbf{0}$ & $-\cdots$ & 0 & - & $4,010,000$ \\
\hline \multicolumn{7}{|c|}{ Exp. II. Mixed culture of five strains: } \\
\hline 0 & 1,720 & 1,880 & 1,260 & 1,580 & 1,950 & 1,900 \\
\hline 22 & 401 & 151 & 279 & 520 & 72,000 & 850,000 \\
\hline 47 & 274 & 80 & 278 & 1,370 & $1,860,000$ & $8,800,000$ \\
\hline 71 & 129 & 69 & 584 & 6,430 & $49,600,000$ & $522,000,000$ \\
\hline 94 & 89 & 105 & 2,000 & 40,000 & $4,000,000,000$ & $4,000,000,000$ \\
\hline 166 & 86 & 57 & $>5,000$ & 107,000 & $1,220,000$ & $3,290,000$ \\
\hline 214 & 97 & 57 & 67,000 & 160,000 & $1,190,000$ & $6,700,000$ \\
\hline 264 & 65 & 42 & 56,000 & 79,000 & 800,000 & $2,800,000$ \\
\hline 336 & 55 & 42 & 44,000 & 83,000 & 850,000 & $2,850,000$ \\
\hline 415 & 58 & 39 & 50,000 & 83,000 & 680,000 & $2,610,000$ \\
\hline 504 & 61 & 56 & 53,000 & 104,000 & 950,000 & $2,690,000$ \\
\hline 576 & 52 & 39 & 49,000 & 70,000 & 660,000 & $2,730,000$ \\
\hline
\end{tabular}

was 10 p.p.m., corresponding to a content of 0.03 p.p.m. Yeastrel, 0.2 p.p.m. peptone, 0.05 p.p.m. glucose, and 0.1 p.p.m. Lemco. The 5-day biochemical oxygen demand $\left(\right.$ at $18.3^{\circ}$ ) of this dilute broth was 0.26 p.p.m. and the oxygen absorbed from acid permanganate in $4 \mathrm{hr}$. at $26 \cdot 7^{\circ}$ was 0.08 p.p.m.

With streptococci no growth was observed in any of the concentrations of broth up to 375 p.p.m. though the period of survival tended to be prolonged as the concentration increased. With 375 p.p.m. broth, survival was so prolonged that there was virtually no diminution in numbers over the test period of 34 days. When the concentration of nutriment rose to 500 p.p.m. slight but definite growth took place. This was 50 times the lowest concentration in which growth of Bact. coli had been observed.

The presence of a minute quantity of organic matter (less than 1 p.p.m.) may induce a profound departure from the true form of the death curve for Bact. coli (Fig. 5). 
Table 2. Effect of small concentrations of nutrient material on viability of Strep. faecalis in $0.003 \mathrm{M}$ phosphate buffer at $\mathrm{pH} 6.0$

(Surviving bacteria as colony counts/ml. of suspension.)

Period of suspension in buffer (hr.)

Concentration of added broth (p.p.m.)

Exp. I. Pure culture of single strain (average results of eight counts):

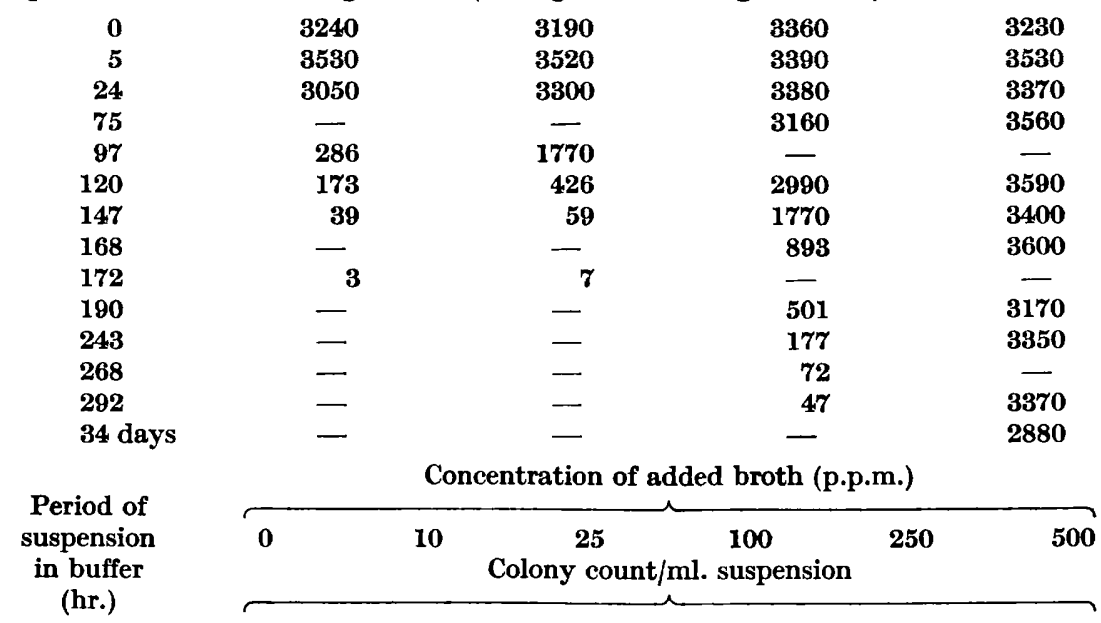

Exp. II. Mixed culture of six strains (average results of four counts):

$\begin{array}{rrrrrrr}0 & \mathbf{4 6 0} & \mathbf{4 2 7} & \mathbf{4 5 7} & \mathbf{4 5 3} & \mathbf{5 5 7} & \mathbf{4 4 0} \\ \mathbf{2 4} & \mathbf{2 1 4} & \mathbf{2 2 9} & \mathbf{2 0 0} & \mathbf{2 3 7} & \mathbf{3 5 6} & \mathbf{3 3 4} \\ \mathbf{7 2} & \mathbf{4 9} & \mathbf{5 7} & \mathbf{5 0} & \mathbf{8 6} & \mathbf{2 0 3} & \mathbf{3 1 9} \\ \mathbf{9 6} & \mathbf{3 2} & \mathbf{3 3} & \mathbf{4 1} & \mathbf{4 9} & \mathbf{1 6 4} & \mathbf{4 6 0} \\ 124 & 19 & 29 & 20 & \mathbf{3 2} & \mathbf{1 3 3} & \mathbf{7 0 0} \\ 163 & \mathbf{9} & 15 & 13 & \mathbf{2 0} & \mathbf{9 9} & \mathbf{6 4 0} \\ 192 & 4 & 10 & \mathbf{9} & \mathbf{1 6} & \mathbf{8 1} & \mathbf{5 9 3} \\ 244 & \mathbf{3} & \mathbf{7} & \mathbf{6} & 15 & \mathbf{7 9} & \mathbf{6 2 3} \\ \mathbf{2 6 4} & - & - & - & - & 77 & \mathbf{1 5 7 3}\end{array}$

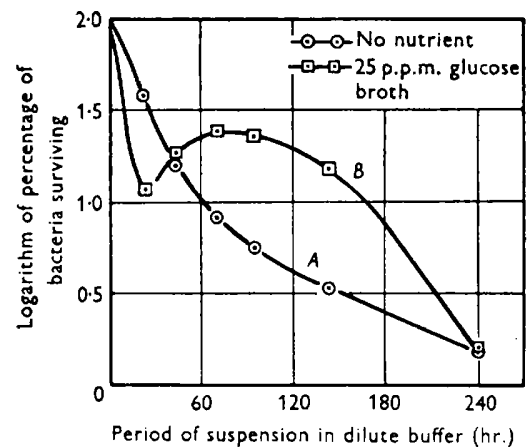

Fig. 5

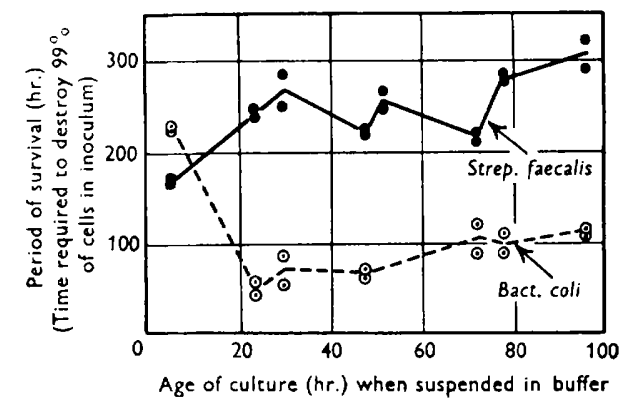

Fig. 6

Fig. 5. Effect of trace of nutrient material on rate of death of Bact. coli in $0.003 \mathrm{M}$ phosphate buffer.

Fig. 6. Periods of survival in $0.003 \mathrm{M}$ phosphate buffer at $\mathrm{pH} 6.0$ of cultures of Bact. coli and Strep. faecalis of different ages. 


\section{Effect of age of cells at time of immersion}

At intervals during incubation (at $37^{\circ}$ ) of broth cultures of the test organisms dilute suspensions were prepared in phosphate buffer at $\mathrm{pH} 6 \cdot 0$, each suspension containing approximately 5 p.p.m. of culture.

The periods of immersion required to destroy $99 \%$ of bacteria are shown for each pair of duplicate bottles in Fig. 6. It is evident that age affected the two species differently, a young culture of Bact. coli being more resistant, and a young culture of Strep. faecalis more sensitive, than older cultures. The period of survival of both organisms tended to increase as the culture aged between 24 and $96 \mathrm{hr}$. With Strep. faecalis this tendency was accompanied by fluctuations in resistance; these were less marked with Bact. coli.

The work described formed part of the programme of the Water Pollution Research Board of the Department of Scientific and Industrial Research and this paper is published by permission of the Department.

\section{REFERENCES}

Bigger, J. W. (1937). The growth of coliform bacilli in water. J. Path. Bact. 44, 167.

Bigger, J. W. \& Nelson, J. H. (1941). The growth of coliform bacilli in distilled water. J. Path Bact. 53, 189.

BigGer, J. W. \& Nelson, J. H. (1943). 'The metabolism of coliform bacilli in distilled water. J. Path. Bact. 55, 321.

Burke, V. \& TASchner, L. (1936). Growth of Escherichia coli in a small amount of organic matter. J. Bact. 32, 124.

Butterfield, C. T. (1929). Experimental studies of natural purification in polluted waters. III. A note on the relation between food concentration in liquid media and bacterial growth. Publ. Hlth Rep., Wash. 44, 2865.

Fox, H. M. \& Wingfield, C. H. (1938). A portable apparatus for the determination of oxygen dissolved in a small volume of water. J. exp. Biol. 15, 437.

Heukelekian, H. \& Heller, A. (1940). Relation between food concentration and surface for bacterial growth. J. Bact. 40, 547 .

Hinshelwood, C. (1951). Decline and death of bacterial populations. Nature, Lond. $167,666$.

Proom, H. \& Hemmons, L. M. (1949). The drying and preservation of bacterial cultures. J. gen. Microbiol. 3, 7 .

Savage, W. G. \& Wood, D. R. (1917). The vitality and viability of streptococci in water. J. Hyg., Camb. 16, 227.

Whipple, G. C. \& MAYer, A. (1906). On the relation between oxygen in water and the longevity of the typhoid bacillus. J. infect. Dis. (Suppl. no. 2), 76.

ZoBELl, C. E. (1943). The effect of solid surfaces upon bacterial activity. J. Bact. 46, 39.

ZoBell, C. E. \& Grant, C. W. (1943). Bacterial utilization of low concentrations of organic matter. J. Bact. 45,555 . 